\title{
Can Differences in Nations' Rule of Law be Explained by Religion?
}

\author{
Chung-yeol Park ${ }^{1^{*}}$ and David L. Skinner ${ }^{2}$ \\ ${ }^{1}$ International Business Management Korea Nazarene University, \\ ${ }^{2}$ Mount Vernon Nazarene University Business School \\ 국가 간의 법규범의 상이함이 종교에 의해 \\ 설명되어 질 수 있는가? \\ 박정열 ${ }^{*}$, 데이비드 스키너 ${ }^{2}$ \\ ${ }^{1}$ 나사렛대학교 오웬스국제대학 국제경영학과 \\ ${ }^{2}$ 마운트 버넌 나사렛 대학교 경영학부
}

\begin{abstract}
This research examines whether religions can explain differences in the rule of law across nations. It finds that several religious groups can explain much of the variation in the rule of law while others have no explanatory power.

요 약 본 논문은 국가들의 법규범의 상이함이 종교에 의해 설명되어 질 수 있는지를 살펴본다. 즉 종교가 법규범 에 영향을 미치는 가의 관계를 조사하는 것이며 그 결과 설명할 수 없는 나라들도 있는 한편 각 나라의 종교 집단 에 따라 법규범에 있어서 변화가 많다는 것을 확인할 수 있다.
\end{abstract}

Key words : Rule of law, Religion, World Justice Project

\section{Introduction}

The rule of law is important to economists, political scientists, business persons and others as are the cultural values that can explain its strength or absence. One possible set of explanatory variables is a country's spectrum of religions. This paper examines the questions of whether certain religions are associated with the rule of law and, if so, in which directions.

The authors are affiliated with an International Business Program at a faith-based Korean university. The students are from a variety of nations (mostly Asian) and religious backgrounds (mostly Christian) and the faculty is composed of committed Christians from the USA, Korea and the Philippines. The inten $t$ of the program is to prepare the students for business careers across cultures where they will face various religious beliefs and attitudes towards the rule of law. It is hoped that they will represent Christianity in their business dealings. The authors' affiliation provides the motivation for researching whether religion can explain the rule of law. Also, empirical studies of the rule of law non-western cultures with non-Christian religions are rare.

The phrase "rule of law" has different meanings to different people. This research uses the World Justice Project (WJP) [16] for a working definition. A quote from the WJP defines rule of law as a rules-based system in which the following four universal principles are upheld:

This work was supported by Korea Nazarene University.

"Corresponding Author : Park, Chung-yeol(cyp4x4@kornu.ac.kr)

Received December 12, 2011 Revised (1st January 30, 2012, 2nd February 7, 2012)

Accepted February 10, 2012 
- The government and its officials and agents are accountable under the law.

- The laws are clear, publicized, stable, and fair, and protect fundamental rights, including the security of persons and property.

- The process by which the laws are enacted, administered, and enforced is accessible, fair and efficient.

- Access to justice is provided by competent, independent, and ethical adjudicators, attorneys or representatives, and judicial officers who are of sufficient number, have adequate resources, and reflect the makeup of the communities they serve.

Each nation has a variety of laws. Whether a nation follows the WJP definition of the rule of law or not varies in practice.

The WJP's Rule of Law Index (RLI) is used to create an empirical measure of the rule of law. This research uses the World Justice Project's Rule of Law Index (RLI)[16] to create a measure of the rule of law. The data for the distribution of various religions is from the World Christian Encyclopedia[17].

Simple linear regressions find that nations with higher percentages of Great Commission Christians, Protestant Christians and Non-Religious citizens have significantly (alpha $=0.01$ ) stronger rule of law. At a weaker alpha of 0.05, Atheists and Muslims are also related to RLI. However, while Atheists are positively related to the RLI, Muslims are negatively related.

The most powerful multiple regression model finds that Great Commission Christians, Protestant Christians and Pentecostal Christians collectively explain $41.7 \%$ of nations' RLI.

The literature is in Section 2, data sources in Section 3 , methodology in Section 4, findings in Section 5, and conclusions in Section 6.

\section{Literature Review}

Law, the rule of law and religion are three disciplines addressed by multitudes of authors over the centuries. That makes it impossible to address all the lines of thought that have been developed in these three areas.
This literature review, therefore, focuses on the intersection of the rule of law and religion. Even that intersection has multiple facets. For example, the impact of the rule of law on religion (laws respecting religious freedom, religious oppression, etc.) will be ignored. The empirical tests described below cannot test cause and effect since longitudinal data are not available for the variables studied. Only "explanation", "prediction" or "relationship" can be tested with available data. However, the impact of religion on the rule of law is the perspective examined in this literature review.

Furthermore, as noted by Jeong[4] most studies of social capital (which includes the rule of law) use western data and only consider Christianity. Studies of non-western cultures are generally not empirical. Also noted is the fact that religious communities are the most significant sources of social capital. Jeong uses data from the 1999-2002 World Values study to show that Protestantism and Catholicism are positively related to civic engagement in Korea, while Buddhism and other religions are not. The Christian relationship with social capital may result from the emphasis on relieving suffering while traditional Buddhism is concentrated on controlling desires which would be unrelated to social capital. The civic engagement of Christians ought to be positively related to the rule of law while the disengagement of Buddhists ought to be unrelated. Within Christianity, Protestantism emphasizes individualism while Catholicism emphasizes solidarity. The Buddhist concept of anatman stresses interconnectedness. Therefore, Catholicism might be closer to Buddhism than to Protestantism. Both Protestantism and Catholicism have high levels of institutionalization (hospitals, colleges, schools, welfare agencies, etc.) while Buddhism does not. Protestantism has a high level of autonomy from the state while Catholicism and Buddhism have low to moderate levels of autonomy. For these reasons, Protestantism may have a more positive relationship with the rule of law, followed by Catholicism and finally Buddhism. Since Jeong examines trust in persons and not in government, the explanation may not irectly transfer. However, it is the only empirical study of the rule of law found that includes a non-western culture and non-Christian religions.

Sherlock[9] notes that from earliest times, human societies have exhibited religious characteristics. Each religious group has 1) a shared worldview, 2) norms that 
are promoted as coming from a divine source, and 3) a system of transcendent punishment for violations. Understanding religion as an adaptive public good is one way of explaining the persistence of religion across cultures since the time human beings first started living in groups. A public good is non-rival and non-excludable. Consumption of a public good by one person does not reduce the supply of that good for another. And, if it is available to one it is available to all. An adaptive public good helps to maintain a society. Religion can help maintain order, encourage approved behavior and punish misbehavior. Since each religious group is different, each may be related to the rule of law in a different way. For example, Judaism, Christianity and Islam point to transcendent punishment imposed by a single God while Hinduism depends on punishment through reincarnation.

The Bible contains numerous covenants between God and his people. The major covenants include: Noahic Covenant (Genesis 8-9), Abrahamic Covenant (Genesis 12-17), Covenant with Isaac (Genesis 27), Covenant with Jacob (Genesis 28), Mosaic Covenant (Exodus 19-24), Israel Covenant (Deuteronomy 29-30), Davidic Covenant (II Samuel 7), and the New Covenant (Jeremiah 30-33 and the New Testament) along with various priestly covenants, national covenants and personal covenants. A covenant corresponds to a contract in modern law. The first five books of the Bible, the Pentateuch, are even called the Books of the Law. The focus of the Bible on covenants and law suggests that Judaism and Christianity would be expected to support the rule of law.

Carroll and Shiflett[3] detail the freedom, equality, tolerance, compassion, charity and abolition of slavery in the history of Christianity. Those characteristics would also be expected to support the rule of law.

Tan[14] discusses the Confucian attempt to balance community and liberty. The former suggests an attachment to the rule of law while the latter rejects it. The traditional view of Confucianism is slanted against individual liberty both in western cultures and even among many Asians. However, Tan points out traditions within Confucian thought that support personal liberty within the bounds of community.

Lee[5] proposes a new category of power to explain Asian cultures' rule of law. Relational power is suggested in addition to the more traditional politico-juridical power and disciplinary power. Politico-juridical power is wielded by a single person and imposed on another. It is most often associated with the rule of law both as power imposed on citizens and as the need for limiting that power. Disciplinary power is not identified with a person but is the result of disciplines such as science and is also coercive. Relational power is developed from interpersonal relationships and is most strongly observed in Confucian societies. In Korea, for example, the family is the principal focus and Korea as a nation is thought of as an extended family. Politico-juridical power is often identified with the rule of law. Disciplinary power is often, though not always, aligned with the rule of law. Relational power is often in conflict with the rule of law. It exhibits itself in examples of cronyism, favoritism or nepotism. Therefore, religions associated with Confucianism are likely to have weaker rule of law.

Nathan[8] writes about the impact of law on modern Korean Buddhism while this study examines the relationship in the opposite direction. The Japanese occupation in the early twentieth century appeared to use law to oppress Buddhism. However, it may have been a vehicle for reform that was already underway. It is interesting to note that a significant part of the law regarding religions centered on propagation. To be legally recognized as a religion in Korea, an organization needed to exhibit some effort to proselytize. That conflict should produce an ambiguous relationship between Buddhism and the rule of law in that country.

Ambuel[1] examines Thailand's constitutional reforms and their relationships with Buddhism. He shows that Buddhism as a justification of political power has declined while Buddhism as a standard for political reform has risen. It has had a strong influence on the types and implementation of reforms.

A collection of papers edited by Turner, Feinerman and Guy[15] discusses the rule of law in China. In particular, it notes the disconnect between codified law and what is enforced by the judicial system. Part of the difference is due to the relational nature of law enforcement in China and that may be explained by its Confucian history. That conclusion is reinforced by McArthur, Englehardt and Jasperson[7]. A small sample of actual judges found that they modified (or felt pressure to modify) actual laws based on their Confucian ethics. 
Arumugam[2] argues that the rule of law is often defined from a western perspective which upholds individual rights while Asian law seems to suppress individual rights in favor of the collective. They also note that little of the research on the rule of law has come from Asia.

Islam's decline from the religion of the world's leading countries to the religion of poor, autocratic ones is related by Lewis[6]. He points to Islam's treatment of women, lack of compromise, lack of separation of church and state, inability to adapt to those it could not conquer, and search for scapegoats.

As an example, the Iranian author Taheri [13] points out that

All but one of the world's remaining military regimes are in Muslim countries. With the exception of Turkey and Bangladesh, there are no real elections in any Muslim country. Of the current 30 active conflicts in the world... 28 concern Muslim governments and/or communities. Two-thirds of the world's political prisoners are held in Muslim countries, which also carry out $80 \%$ of all executions each year.

Since 2001, Iraq has held elections, but remains unstable. The qualities of Islam would be expected to undermine the rule of law.

Skinner found that much of the variation in the Index of Economic Freedom[10], the Globalization Index[11] and Failed States Index[12] can be explained by religion. The rule of law is one feature of nations which have been economically successful. Business people and others need to depend on the rule of law for their success.

The literature suggests that religion should be related to the rule of law. Empirical tests of non-western rule of law and non-Christian religions are lacking. The empirical questions of (1) which religions are associated with the rule of law and (2) the directions of the relationships are the focus of this paper.

\section{Data Sources}

World Justice Project's (WJP) Rule of Law Index (RLI)[16] is used to create a measure of the rule of law. WJP reports eight dimensions constructed from more than 400 variables drawn from the responses of 66,000 ordinary citizens and 2,000 legal experts. The eight factors are:

- Limited government powers

- Absence of corruption

- Order and security

- Fundamental rights

- Open government

- Effective regulatory enforcement

- Access to civil justice

- Effective criminal justice

The eight factors help to "flesh out" the working definition of "rule of law" given earlier. It is instructive for purposes of this study to note that none of these factors focuses on religion. Each factor is a normalized sum of its inputs. No overall composite is score is reported by the WJP. For this study a composite score is found by averaging the eight factors for each country, a methodology not inconsistent with that used by WJP. This composite is used as the dependent variable.

The World Christian Encyclopedia[17] contains data on the religious spectrums of nations broken down into various Christian subcategories and by other major religions. All the 66 countries covered by the RLI are included except Hong Kong so $\mathrm{n}=65$ for this study.

The broad Christian classes include:

- Christian

- Roman Catholic

- Protestant

- Anglican

- Orthodox

- Independent

- Evangelical

- Pentecostal/Charismatic

- Great Commission Christians

Other religious groups include:

- Muslim

- Jewish

- Baha'i

- Buddhist

- Hindu

- Spiritist / Ethnoreligionist / Chinese folk religion

- Nonreligious

- Atheist 
Some of these categories are clear but since others of these may not be, the following definitions are quoted from the World Christian Encyclopedia[17].

Independents. Separated from, uninterested in, and independent of historic denominationalist Christianity.

Evangelicals. A subdivision mainly of Protestants consisting of all affiliated church members calling themselves Evangelicals, or all persons belonging to Evangelical congregations, churches or denominations: characterized by commitment to personal religion.

Charismatics. Baptized members affiliated to nonpentecostal denominations who have entered into the experience of being filled with the Holy Spirit.

Great Commission Christians. Believers in Jesus Christ who are aware of the implications of Christ's Great Commission, who have accepted its personal challenge in their lives and ministries, are attempting to obey His commands and mandates, and who are seeking to influence the body of Christ to implement it.

Ethnoreligionists. Followers of a non-Christian or pre-Christian religion tied closely to a specific ethnic group, with membership restricted to that group; usually animists, polytheists, or shamanists. Older terminology: pagans, heathens, tribal religionists, traditional religionists. [In this paper the term is also used to include Chinese folk religionists and spiritists.]

Nonreligious. Persons professing no religion, no interest in religion; secularists, materialists; agnostics, but not militantly antireligious or atheists.

Atheists. Militantly anti-religious or anti-Christian agnostics, secularists, or arxists.

There are obvious data limitations. RLI measures are reported for 66 countries for 2011. Religions may not be defined in a way that appeals to every reader. Categories are not mutually exclusive: A Protestant Christian may also be Evangelical and Pentecostal. Some data may be contradictory: Haitians who claim to be Roman Catholics and also practice Voodoo (an Ethnoreligion) may be theologically impossible but occur in the real world. In addition, the data are self reported: A respondent may claim to be a Great Commission Christian but his/her neighbors may be unaware of that. The white noise resulting from these data limitations may understate religion's explanatory power.

\section{Methodology}

First, an OLS regression is run with each individual religion as the independent variable and RLI as the dependent variable to determine the direction and significance of individual relationships and the percentage of the variation in RLI that is explained ( $\mathrm{R}$ square).

Second, stepwise multiple regression is used to find the most effective 2-factor model, 3-factor model, etc. No theoretical order of entry is imposed since no particular theory is being tested other than to determine whether religions predict RLI. The significance of results is allowed to determine order. Due to data limitations described above, multicollinearity is expected. Correlations between the various religions run from -0.68 to +0.78 with more than $5 \%$ of the correlations having an absolute value greater than 0.5 . Therefore, the percentage of the variation in the RLI explained by a set of religion variables is less than the sum of the percentages explained by the religions individually.

A more complex model is not considered an improvement over a simpler one unless its increase in explanatory power justifies its increase in complexity. An $F$ test is used to determine whether a larger model is significantly better than a smaller model:

$$
\begin{gathered}
\mathrm{F}=\left[\left(\mathrm{R}_{\mathrm{L}}^{2}-\mathrm{R}_{\mathrm{S}}^{2}\right) /\left(\mathrm{k}_{\mathrm{L}}-\mathrm{k}_{\mathrm{S}}\right)\right] /\left[\left(1-\mathrm{R}_{\mathrm{L}}^{2}\right) /\left(\mathrm{N}-\mathrm{k}_{\mathrm{L}}-1\right)\right] \\
\text { where: } \mathrm{df}^{=}\left(\mathrm{N}-\mathrm{k}_{\mathrm{L}}-1\right),\left(\mathrm{N}-\mathrm{k}_{\mathrm{S}}-1\right) \\
\mathrm{R}_{\mathrm{L}}^{2}=\text { the } \mathrm{R}^{2} \text { of the larger model (more } \\
\quad \text { religious groups), } \\
\mathrm{R}_{\mathrm{S}}^{2}=\text { the } \mathrm{R}^{2} \text { of the smaller model, } \\
\mathrm{k}_{\mathrm{L}}=\text { the number of religious groups in the } \\
\quad \text { larger model, } \\
\mathrm{k}_{\mathrm{S}}=\text { the number of religious groups in the } \\
\quad \text { smaller model, and } \mathrm{N}=\text { the sample size. }
\end{gathered}
$$

Adjusted $\mathrm{R}^{2}$ is used throughout to avoid the upward bias of the unadjusted $R^{2}$.

\section{Findings}

Table 1 summarizes the findings of the RLI composite regressed individually on each religion. It reports the correlation, slope, adjusted $\mathrm{R}^{2}$ and significance level. Religious categories are listed from the strongest predictor 
to the weakest. The top three religions are significant at the 0.01 level. The next two are not significant at 0.01 but are significant at 0.05 .

The slope indicates the change in RLI associated with a one percent increase in the religion's fraction of the population. A positive correlation or slope indicates a positive relationship with the rule of law. The only religion that exhibits a significant negative correlation with RLI is Muslims.

The significance level is shown to three decimals although some are so significant that scientific notation is reported. In the text, significance levels are reported in parentheses.

$\mathrm{R}^{2}$ indicates the proportion of the variability in RLI explained by that religion. Adjusted $\mathrm{R}^{2}$ is reported to avoid the upward bias of the unadjusted $\mathrm{R}^{2}$. Some are negative and must be interpreted as meaningless (na).

The strongest relationship is for Great Commission Christians which explains $32.4 \%$ of the variation in RLI. For each additional percent of Great Commission Christians in the population, a country's RLI increases an average of 0.0057 . Nations with more Great Commission Christians have significantly (.000) greater rule of law.

The other significant predictors at the 0.01 level are Protestants which explain $18.2 \% \quad(0.000)$ and the Non-Religious which explain $10.0 \%$ (0.006). For each additional percent of those groups, the RLI rises 0.0032 and 0.0048 respectively. At the 0.05 level are Atheists $7.2 \%$ (0.018), and Muslims 4.8\% (0.044). For each additional percent of Atheists, the RLI rises 0.0109. The most troubling results are for Muslims in that they are the only significant religious group with a negative sign. For each additional percent of Muslims a country has, the RLI changes -0.0011 .

[Table 1] Simple Regressions on RLI

\begin{tabular}{|l|rccr|}
\hline \multicolumn{1}{|c|}{ Religion } & Correlation & Slope & $\mathrm{R}^{2}$ & Significance \\
\hline Great Commission Christians & 0.578 & 0.0057 & 0.324 & $4.489 \mathrm{E}-07$ \\
Protestants & 0.422 & 0.0032 & 0.182 & $2.311 \mathrm{E}-04$ \\
Non-Religious & 0.338 & 0.0048 & 0.100 & 0.006 \\
\hline & & & & \\
\hline Atheist & 0.293 & 0.0109 & 0.072 & 0.018 \\
Muslim & -0.251 & -0.0011 & 0.048 & 0.044 \\
\hline & & & & \\
\hline Jew & 0.206 & 0.0673 & 0.027 & 0.099 \\
Spiritist/Ethnoreligions/Chines & -0.168 & -0.0024 & 0.013 & 0.180 \\
e folk religion & 0.158 & 0.0006 & 0.009 & 0.210 \\
Christians & & & &
\end{tabular}

\begin{tabular}{|l|rrrr} 
Orthodox & -0.152 & -0.0012 & 0.008 & 0.226 \\
Baha'i & -0.138 & -0.0356 & 0.003 & 0.274 \\
Anglicans & 0.131 & 0.0020 & na & 0.297 \\
Independent Christians & -0.103 & -0.0023 & na & 0.386 \\
Hindu & -0.105 & -0.0015 & na & 0.405 \\
Evangelical Christians & 0.109 & 0.0026 & na & 0.412 \\
Pentecostal/Charismatic & -0.067 & -0.0007 & na & 0.594 \\
Christians & -0.048 & -0.0002 & na & 0.702 \\
Roman Catholics & -0.024 & -0.0002 & na & 0.850 \\
Buddhist & & & &
\end{tabular}

The other religions (Jews, Spiritist/Ethnoreligions/Chinese Folk religions, Orthodox Christians, Baha'is, Anglicans, Christians as a whole, Independent Christians, Hindus, Evangelical Christians, Pentecostal/Charismatic Christians, Roman Catholics and Buddhists) have no ability to predict RLI individually.

Stepwise regression of the RLI on multiple religions results in numerous models that are significantly better than simpler models. Only the best 2-factor model and 3-factor model are reported here.

The religion variables suffer from multicollinearity. Regression assigns a significance to each religion based its contribution after the other religions in the model have been accounted for. With correlated religions, the reported significance of each is downgraded.

The best single-factor model involves Great Commission Christians (GCC) with an $\mathrm{R}^{2}$ of 0.280 . That means GCC explains $28.0 \%$ of the variation in RLI. The best multiple regression models will be given next. Since the sizes and signs of the coefficients are similar, a more complete description will follow the multiple regression models.

The best 2-factor model employs GCC and Protestants and has an $\mathrm{R}^{2}$ of $37.7 \%$. An $\mathrm{F}$ test shows this 2-factor model is significantly $(0.000)$ better than the best 1 -factor model.

Best 2-Factor model: $\mathrm{R}^{2}=37.7 \%(000)$.

$$
\begin{aligned}
\text { RLI }= & 0.5056+0.0047 \mathrm{GCC}+0.0020 \text { Protestant } \\
& (0.000)(0.000)
\end{aligned}
$$

There are also two other 2-factor models that are significantly better than the best 1 -factor model. One includes GCC and the non religious. The model's $\mathrm{R}^{2}$ is $34.3 \%$ (0.011). The other includes GCC and Atheists with an $\mathrm{R}^{2}$ of $34.2 \%(0.021)$. In each case, the GCC coefficient rounds to 0.005 as in the best model and the second factor's coefficient is positive so all these explanatory 
variables are positively related to the rule of law.

The best 3-factor model contains GCC, Protestants and Pentecostal/Charismatic Christians. The $\mathrm{R}^{2}$ is $41.7 \%$ and an $\mathrm{F}$ test shows this 3 -factor model is significantly $(0.000)$ better than the best 2-factor model.

Best 3-Factor model: $\quad \mathrm{R}^{2}=41.7 \%(0.000)$.

$\mathrm{RLI}=0.5280+0.0047 \mathrm{GCC}+0.0025$ Protestant -0.0025 Pente costal

(0.000) (0.000) (0.002)

There are four additional 3-factor models that are also significantly better than the best 2-factor model. They all include GCC and Protestants. In each case, the GCC coefficient ranges from 0.004 to 0.006 and the Protestants coefficient from 0.002 to 0.003 . The third factor in each varies from Independent Christians $\left(-, \quad R^{2}=41.0 \%\right.$, significance 0.000), Evangelical Christians (-, $\mathrm{R}^{2}=40.7 \%$, significance 0.000$)$, the Non-Religious $\left(+, R^{2}=40.5 \%\right.$, significance 0.000$)$ to Christians as a whole $\left(-, R^{2}=39.5 \%\right.$, significance 0.010$)$. The sign indicates the direction of the relationship for each.

No 4-factor model was significantly better than the best 3-factor one.

As noted above, in each instance the $\mathrm{F}$ test shows that the larger model is significantly better than the previous one at predicting the dependent variable. The signs of the common coefficients are the same and their sizes are similar. For example, the coefficients for GCC are 0.0057, 0.0056 and 0.0047 for the 1-, 2- and 3-factor models. That means that a $1 \%$ increase in GCC in a nation is associated with an increase of about 0.005 or 0.006 in the RLI composite. Great Commission Christians are positively associated with more rule of law.

Similarly, increased presence of Protestants is associated with greater rule of law. The 1-, 2- and 3 -factor coefficients are $0.0032,0.0019$ and 0.0026 . A $1 \%$ increase in Protestants is associated with a 0.02 or 0.03 increase in the RLI composite.

Conversely Pentecostal/Charismatic Christians are negatively associated with the rule of law. The 1- and 3 -factor coefficients are -0.0007 and -0.0025 . A $1 \%$ increase in Pentecostal/Charismatic Christians is associated with a negative change in the RLI composite.

The $\mathrm{R}^{2}$ Great Commission Christians shows that $32.4 \%$ of the difference in the rule of law can be explained by one religious group. The $\mathrm{R}^{2}$ of the 3-factor model indicates that the set of three religious variables can explain $41.7 \%$ of the RLI composite. A high $\mathrm{R}^{2}$ might have been expected if religion was among the 8 factors that compose the RLI. Since religion was not directly included in the indicators, the results are striking.

\section{Conclusions}

This paper examines the relationships between a simple composite of the Rule of Law Index (RLI) factors and the distribution of various religions.

Simple regression results indicate that nations with higher percentages of three religious groups are associated with significantly $(0.01)$ greater rule of law. They are $\left(R^{2}\right.$ in parentheses) Great Commission Christians (32.4\%), Protestants (18.2\%) and the Non-religious (10.0\%). Two others also produce significant results at the 0.05 level. Atheists $(7.2 \%)$ are associated with more rule of law and Muslims (4.8\%) are associated with less.

Stepwise regression results produced models with two and three factors. An F test was employed to determine whether each model was significantly better than the previous one. The most complete model is:

\section{$\mathrm{RLI}=0.5280+0.0047 \mathrm{GCC}+0.0025$ Protestant -0.0025 Pentecostal
(0.000)
$(0.000)$
(0.002)

This 3-factor model explains $41.7 \%$ of the variation in the composite constructed from the Rule of Law Index (RLI) even though the Index doesn't explicitly contain religion as an indicator. Jeong[4] is the only empirical study found that is close to the intent of this paper. And, its R2is only about $8 \%$ whereas this study has an R square of almost $42 \%$.

As the RLI is expanded to more nations, the questions of this study should be reexamined to verify whether results are consistent with a larger data set.

Although causality is not claimed, most of these world religions have existed for centuries or millennia and the rule of law is evolving, so it is logical to conclude that if there is a cause and effect, religion impacts the rule of 
law and not the other way around.

The question of whether certain religions are associated with the rule of law can be answered in the affirmative.

As noted by Sherlock[9] theologians of various stripes generally expect that their beliefs ought to be reflected in the lives of their faiths' followers and this study provides some evidence to support those expectations, but only for certain religions. Those from the Great Commission Christian and the Protestant Christian traditions should be pleased, but not surprised, to find there is a positive relationship between their adherents and the rule of law. Carroll and Shiflett[3] would expect that.

The positive relationship between the non religious or the atheists and the rule of law requires further study. It isn't obvious why those without a faith would be associated with more rule of law. Perhaps one might speculate that those without a faith see the rule of law as providing a structure that is a replacement for a religion. This is an avenue for further research.

The negative relationship between Muslims and the rule of law is disturbing. It is possible that the WJP's definition of rule of law is "western" and biased against those countries with large Muslim populations in line with Arumugam[2]. Or, it is possible that there is something about the Muslim faith that is antithetical to the rule of law as noted by Lewis[6] and Taheri[13]. Again, that provides an opportunity for further research.

The lack of relationship between the other faiths and the rule of law will probably disappoint the theologians from those faiths. It seems that many religions "don't matter" from a rule of law perspective. That is consistent with Jeong[4]; Tan[14]; Nathan[8]; Turner, Feinerman and Guy[15] and Lee[5].

From a practical viewpoint, business people and others would do well to recognize that there are cultural factors, such as religion, which help to explain the ease or difficulty of engaging in international commerce in particular countries. Before doing business in another culture, it would help to think about the religions practiced there

\section{References}

[1] Ambuel, D., New karma: buddhist democracy and the rule of law in thailand. American Asian Review, 59(4), pp. 131-162, 2001.

[2] Arumugam, R., ed., Asian Discourses of Rule of Law: Theories and Implementation of Rule of Law in Twelve Asian Countries, France and the U.S. Singapore : Institute of Southeast Asian Studies, 2005.

[3] Carroll, V., \& Shiflett, D., Christianity on trial. Jackson, TN: Encounter, 2001.

[4] Jeong, H. O., How do religions differ in their impact on individuals' social capital? The case of south korea. Nonprofit \& Voluntary Sector Quarterly, 39(1), pp.142-160, 2010.

[5] Lee, C. W., The rule of law and forms of power: theorizing the social foundations of the rule of law in korea. Korea Journal, pp.5-28, 2009.

[6] Lewis, B., What went wrong? The clash between islam and modernity in the middle east. Oxford: Oxford Press, 2001.

[7] McArthur, D. N., Englehardt, E. E., \& Jasperson, J. O., Progress toward the rule of law in china: "Democratizing" the demands of law with confucian ethics. International Journal of Applied Philosophy, 23(2), pp. 249-270, 2009.

[8] Nathan, M. A., The encounter of buddhism and law in early twentieth-century korea. Journal of Law and Religion, 25(1), pp. 1-32, 2009-10.

[9] Sherlock, R., Religiosity as a public good. Politics and the Life Sciences, 27(2), pp. 2-12, 2009.

[10] Skinner, D. L. Are christian nations economically free? Proceedings of the 18th Annual Christian Business Faculty Association Conference, 2002.

[11] Skinner, D. L. Globalization and religion. International Business \& Economic Research Journal, 2(5) pp. 61-66, 2003.

[12] Skinner, D. L. Can the risk of state failure be explained by religion? Proceedings of the 17th Annual Conference of the American Society of Business and Behavioral Sciences, 2010.

[13] Taheri, A. Islam can't escape blame for sept. 11. Wall Street Journal, p. A22, Oct. 24, 2001.

[14] Tan, S. H., From cannibalism to empowerment: an analects-inspired attempt to balance community and liberty. Philosophy East and West, 54(1), pp. 52-70, 2004.

[15] Turner, K. G., Feinerman, J. V., \& Guy, R. K. eds., The Limits of the Rule of Law in China. Seattle: University of Washington Press, 2000.

[16] The World Justice Project Rule of Law Index. 
Washington, DC.: World Justice Project, 2011.

[17] World Christian Encyclopedia 2nd, Vol.1 .NYC:

Oxford University Press, 2001.9.

\section{Chung-yeol Park}

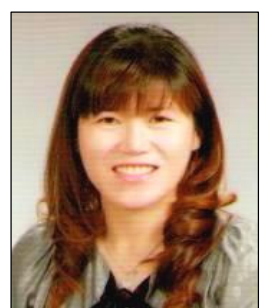

- Feb. 1992 : Sookmyung Women's Univ., English Literature, MS

- Dec. 2004 : Oklahoma City Univ., TESOL, MS

- Feb. 1999 : Sookmyung Women's Univ., English Literature, PhD

- Jan. $2007 \sim$ Dec. 2008 : California State Univ., Dept. of Education, Visiting Professor

- Aug. $2009 \sim$ current : Korea Nazarene Univ., Owens International College, International Business Management, Professor

$<$ Research Interests $>$

International Business Management, Language Education

\section{David L. Skinner}

[Regular member]

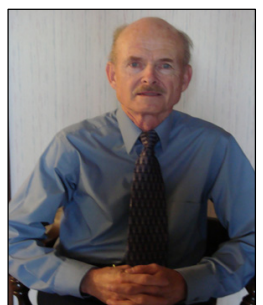

- Dec. 1968 : Michigan State University, Mathematics, MAT

- Aug. 1978 : Governors State University, Business Administration, MA

- Dec. 1987 : Michigan State University, Finance, $\mathrm{PhD}$.

- Aug. $2009 \sim$ current : Korea Nazarene University, Owens International College

- Aug. $1998 \sim$ current : Mount Vernon Nazarene University, Business School

$<$ Research Interests $>$

Religion and Economics 